\title{
Study on the Impact of Monetary Policy on Corporate Investment
}

\section{Behavior}

\author{
Jun Duan ${ }^{1,2, *}$ and Xiaolin Pan \\ ${ }^{1}$ Chongqing University 400044 \\ ${ }^{1,2}$ Chongqing Normal University, 401331, China
}

Key Words. Monetary Policy, Enterprise level, Enterprise Capital

\begin{abstract}
This paper explores how the enterprise level affects the enterprise investment behavior from the research perspective of the monetary policy in the government macroeconomic policy. Based on the empirical study of the quarterly data from 2007 to 2015 in listed companies of A-share, this paper has found: when the Central Bank implements tight monetary policies, the enterprise level has a weakened impact on the corporate investment scale. However, due to the buffer action of the internal capital market, the monetary policy has comparatively small impact on the corporate investment scale.
\end{abstract}

\section{Introduction}

The macroeconomic policy is not only the leading indicator that affects the corporate investment behavior, but also the uncontrollable element of external economic environment confronted by micro business decisions. As one of the most important aspects of the macro-control, the monetary policy plays a vital role in regulating the micro enterprise behavior and influencing the tendency of macro-economy (Guogang Wang, 2012a) ${ }^{[1]}$. Our country has gradually established the regulation mechanism of monetary policy since reform and opening up, and in order to fulfill the established policy goals - price stabilization, promotion of economic growth, as well as full employment and balance of payments, the Central Bank has made full use of various monetary policy tools such as money supply, interest rate, deposit reserves and rediscount rate, etc. to regulate the counter business cycle, hoping that the implementation of monetary policy will contribute to picking up the decline of economic growth or curbing the overheated economic activities, preventing asset bubbles and so on. On a micro level, whether or not the monetary policy will have this counter-cyclical effect depends on the reaction level of corporate investment behavior on the monetary policy. According to economic theories, the monetary policy has an effect on the economic system mainly via monetary channel and credit channel (Bernanke and Blinder,1992) ${ }^{[2]}$, and its influence mechanism lies in increasing or decreasing the financing cost of the company, thus influencing the financing scale as well as the corporate investment behavior (Kashyap et al, 1993) ${ }^{[3]}$.

Based on the macro-economics, the study on the traditional macro monetary policy and the economic output mainly explores the influence of the monetary policy on the macro economic aggregate. In recent years, research on the influence of the monetary policy on investment activities both at home and abroad focuses on the relationship between the monetary policy and the macro investment by analyzing the data from macro regions or the industry level (Weiwei Ying, 2008) ${ }^{[4]}$. Yet, there is little research on the present situation of the gap between the micro corporate investment behavior and the macro economic policies (Guohua Jiang and Pingui Rao, 2011) ${ }^{[5]}$. 
Therefore, to probe into the micro effect of the transmission mechanism of the monetary policy by bringing the national macroeconomic policy into the research on the micro corporate investment behavior will contribute to an overall analysis of the factors influencing the decision options of corporate investment, as well as the study on the right judgment of the effective practice of the macro economic policy in micro economic units, thus offering policy-oriented suggestions on working out appropriate economic policies to the government decision-making department.

Although the monetary policy has an independent influence on corporate investment activities, now there is little research on how monetary transmission channel affects micro corporate investment activities, as well as the difference in the transmission mechanism in various organizational structure of the enterprise. Since La Porta, etc.(1999) ${ }^{[6]}$ revealed that a great number of companies have ultimate controllers and about $26 \%$ of the ultimate controlling shareholders adopted the enterprise level, many scholars have found, by using La Porta's research method, that the enterprise level is a kind of the corporate organizational form extensively existing throughout the world. Why enterprise groups choose the enterprise level is that this structure has an advantage in financing, especially in areas where protection for investors is weak. From the aspect of financing constraints in the capital market, the fact that most enterprise groups adopts the pyramid organizational structure can be attributed to two factors, on the one hand, the existence of the enterprise level helps form an internal capital market in member enterprises, thus making them solve financing problems via internal money dealings and relieve the financing constraints in the external capital market (Friedman, etc., 2003; Fan, 2010) ${ }^{[7][8]}$, on the other hand, the enterprise level can help enterprise group members get debt financing from the external capital market. For example, they can improve their financing capacity via the guarantee of the parent company (Berger, Ofek,1995) ${ }^{[9]}$, or they can scale up debt financing via the leverage effect of the enterprise level, and moreover, the more the levels of the enterprise level, the bigger the leverage effect (Zengquan Li, Xiangang Xin and Xuhui Yu, 2008) ${ }^{[10]}$. Hence, if we ignore the difference in the corporate organizational structure and the function of the pyramid control level, we will find it hard to look into how micro company levels react to the regulation of the monetary policy, as well as whether there is a remarkable difference in the reaction to the regulation of the monetary policy by companies with various control levels and property types.

In conclusion, this paper will explore the transmission mechanism in corporate investment activities by the macro monetary policy under the various corporate organizational structures in our country, based on the most recent research findings on neoinstitutional economics, macro monetary theories, and theories of corporate investment activities. The research hypothesis proposed by this paper is that the tightness of the monetary policy is in negative correlation to the investment spending of the company, while the increase in the enterprise level is in positive correlation to the investment spending and weakens the negative correlation between the monetary policy and the investment spending.

\section{Model Establishment of the Impact of Monetary Policy on Corporate Investment Behavior}

This paper requires three groups of variables: the first group is explained variables, that is the capital investment scale of listed companies; the second group is explaining variables, including the tightness index of the monetary policy and the control level of the pyramid ownership structure; the third group is control variables, which means variables such as the growth ability of company, cash holding level, profitability , financial leverage, scale of company and time to market, etc. introduced according to the research results on the influencing factors of corporate investment behaviors by 
Richardson(2006) ${ }^{[11]}$ as well as many scholars in our country. The specific definitions of research variables can be seen in Table.1.

Table. 1 Chart of Research Variables

\begin{tabular}{|c|c|c|}
\hline $\begin{array}{l}\text { Variable } \\
\text { Symbol }\end{array}$ & Variable Name & Variable Definition \\
\hline \multicolumn{3}{|c|}{ Explained Variable } \\
\hline $\mathrm{I}_{\mathrm{t}}$ & $\begin{array}{l}\text { Investment } \\
\quad \text { Scale }\end{array}$ & $\begin{array}{l}\text { To build quarterly fixed assets, intangible assets, } \\
\text { and other cash/ quarter total assets paid by } \\
\text { long-term assets }\end{array}$ \\
\hline \multicolumn{3}{|c|}{ Explaining Variables } \\
\hline Layer & $\begin{array}{l}\text { enterprise } \\
\text { level }\end{array}$ & $\begin{array}{l}\text { The number of the longest controlling chains } \\
\text { between ultimate controllers and } \\
\text { companies( there is only one controlling chain } \\
\text { between ultimate controllers and company, the } \\
\text { enterprise level is 1). }\end{array}$ \\
\hline $\mathrm{MP} 1_{\mathrm{t}}$ & $\begin{array}{l}\text { Tightness of } \\
\text { Monetary } \\
\text { Policy }\end{array}$ & $\begin{array}{l}\text { The growth rate of generalized money supply } \\
\text { M2 }\end{array}$ \\
\hline \multicolumn{3}{|c|}{ Control Variables } \\
\hline Size & Enterprise Size & $\begin{array}{l}\text { The natural logarithm of total assets } \\
\text { (The operating income of the current quarter- }\end{array}$ \\
\hline Growth & Growth ability & $\begin{array}{l}\text { the operating income of the previous } \\
\text { quarter)/the operating income of the previous } \\
\text { quarter }\end{array}$ \\
\hline ROA & Profitability & total assets yield \\
\hline Lev & $\begin{array}{l}\text { Financing } \\
\text { Leverage }\end{array}$ & Gross liability/total assets \\
\hline $\mathrm{CF}_{\mathrm{t}}$ & $\begin{array}{l}\text { Operational } \\
\text { Cash Flow }\end{array}$ & $\begin{array}{l}\text { The cash flow in the quarterly business } \\
\text { activities/total assets }\end{array}$ \\
\hline Age & $\begin{array}{l}\text { Time to } \\
\text { Market }\end{array}$ & $\begin{array}{l}\text { The natural logarithm of the age of listed } \\
\text { company }\end{array}$ \\
\hline Gdp & $\begin{array}{l}\text { Economic } \\
\text { Growth }\end{array}$ & The natural logarithm of GDP \\
\hline Year & $\begin{array}{l}\text { Yearly Control } \\
\text { Variable }\end{array}$ & $\begin{array}{l}\text { Making the year } 2007 \text { a benchmark, we use } 6 \\
\text { yearly dummy variables. }\end{array}$ \\
\hline IND & $\begin{array}{l}\text { Industry } \\
\text { Control } \\
\text { Variable }\end{array}$ & $\begin{array}{l}\text { Based on the industry classification guidance } \\
\text { issued by CSRC, the manufacturing industry } \\
\text { can be sorted into } 10 \text { types, totaling } 20 \text { dummy } \\
\text { variables }\end{array}$ \\
\hline Quarter & $\begin{array}{l}\text { Quarterly } \\
\text { Control } \\
\text { Variable }\end{array}$ & $\begin{array}{l}\text { Making the first quarter a benchmark, we use } 3 \\
\text { quarterly dummy variables. }\end{array}$ \\
\hline
\end{tabular}

The first to test is what influence the tightness of the monetary policy has on corporate investment activities, and then to analyze how much influence the monetary policy has corporate investment activities. So, in order to test the above assumptions, the following econometric models are built, Control being the relative control variable. 


$$
\begin{aligned}
I_{t}= & \beta_{0}+\beta_{1} M P+\beta_{2} C F_{t}+\sum \text { Control }+\sum \text { Ind } \\
& +\sum \text { Year }+\sum \text { Quarter }+\varepsilon \\
I_{t}= & \beta_{0}+\beta_{1} \text { layer }+\beta_{2} M P+\beta_{3} \text { layer } * M P+\beta_{4} C F_{t}+\sum \text { Control } \\
& +\sum \text { Ind }+\sum \text { Year }+\sum \text { Quarter }+\theta
\end{aligned}
$$

The annual data range of this paper is from 2007 to 2015, totaling 9 years of data. The quarterly data used, compared with the yearly data, can make the most of the data of money supply, thus better reflecting the tightness of the current monetary policy. According to research practice, sample selection excludes: listed companies in the field of finance and real estate; ST, PT companies; companies which made major transactions in asset between 2007 and 2015, leading to dramatic changes in business activities; all companies with missing data and abnormal values. And in the end we get 30561 company/quarterly observed values from 1331 companies.

The research data mainly comes from the financial figures of common listed companies in CSMAR and Wind data base, while the relative data of the enterprise level is obtained from the annual report data of listed companies via manual query, and data of money supply and GDP comes from the websites of the People's Bank of China and the State Statistical Bureau. In the course of regression, we make $1 \%$ of Winsorize disposal of all the continuous variables except dummy variables to weaken the influence of the outlier. Besides, this paper uses Excel 2010 disposal data and Stata12.0 analysis and disposal data.

\section{Empirical Results and Analysis}

First of all, we use research samples to make descriptive statistics of major variables, and the result can be seen in Table. 2. We can see from Table. 2 that the total number of valid observed values in this paper is 30561 and the mean value of $\mathrm{I}$ is 0.0978 , which means the investment spending of sample companies account for $9.78 \%$ of the total assets, the median being 0.0092 and samples being even, so there exist some companies with big investment rates. According to statistical result of the tightness of the monetary policy, the mean value and the median of MP1 are respectively 0.1730 and 0.1757 , indicating samples are even; the mean value and the median of MP2 are both negative, indicating the speed of money supply exceeds the growth rate of GDP. The mean value of the enterprise level is 2.73 , the median is only 3 layers, with the maximum 9 and the minimum 1, indicating big difference in the internal structure. Descriptive statistical features of other variables are consistent with the mainstream literature.

Table. 2: Descriptive Statistics of Major Variables

\begin{tabular}{ccccccc}
\hline & Obs & Mean & Median & Std.Dev. & Min & Max \\
\hline I & 28497 & 0.0978 & 0.0092 & 0.0236 & -0.0091 & 0.1280 \\
Cf & 28497 & 0.0223 & 0.0190 & 0.0439 & -0.3240 & 0.1530 \\
MP 1 & 28497 & 0.1730 & 0.1757 & 0.0628 & 0.0790 & 0.3240 \\
Layer & 28497 & 2.730 & 3 & 0.5840 & 1 & 9 \\
ROA & 28497 & 0.045 & 0.039 & 0.061 & -0.37 & 1.938 \\
Growth & 28497 & 0.1500 & 0.0343 & 0.6690 & -0.8420 & 4.4190 \\
Lev & 28497 & 0.4910 & 0.4964 & 0.2170 & 0.0506 & 1.2410 \\
CF & 28497 & 0.0494 & 0.0513 & 0.074 & -0.5020 & 0.6060 \\
Size & 28497 & 21.4600 & 21.3220 & 1.1670 & 16.5300 & 28.2600 \\
Age & 28497 & 1.9810 & 2.2072 & 0.7320 & 0.0100 & 3.1010 \\
Gdp & 28497 & 1.9200 & 1.9433 & 0.4340 & 1.0600 & 2.7100 \\
\hline
\end{tabular}


The Multiple regression Analysis of the Investment Scale. Use measurement models (1) and (2) to test the previous assumption, and the result can be seen in Table 3.

Table.3 The Regression Analysis of the Monetary Policy, the enterprise level and the Corporate Investment Scale

\begin{tabular}{|c|c|c|c|c|}
\hline \multirow[t]{2}{*}{ Variable } & \multicolumn{2}{|c|}{ Dependent Variable $\left(\mathrm{I}_{\mathrm{t}}\right)$} & \multicolumn{2}{|c|}{ Dependent Variable $\left(\mathrm{I}_{\mathrm{t}}\right)$} \\
\hline & \multicolumn{2}{|c|}{ Model 1} & \multicolumn{2}{|c|}{ Model 2} \\
\hline \multirow[t]{2}{*}{ MP } & $-0.94^{* *}$ & $-0.061^{*}$ & $-0.083^{* *}$ & $-0.072^{* *}$ \\
\hline & -2.248 & -1.658 & -2.473 & -2.251 \\
\hline \multirow[t]{2}{*}{ layer } & - & - & $0.004^{* *}$ & $.003^{*}$ \\
\hline & - & - & 2.00 & 1.87 \\
\hline \multirow[t]{2}{*}{$\mathrm{CF}$} & $0.386^{* * *}$ & $0.392^{* * *}$ & $0.749^{* * *}$ & $0.785^{* * *}$ \\
\hline & 21.51 & 21.73 & 22.83 & 25.49 \\
\hline \multirow[t]{2}{*}{ MP*layer } & - & - & $0.017^{* *}$ & $0.016^{* *}$ \\
\hline & - & - & 2.334 & 2.187 \\
\hline \multirow[t]{2}{*}{ Lev } & & $0.025^{* * *}$ & & $0.326^{* * *}$ \\
\hline & & 10.91 & & 80.20 \\
\hline \multirow[t]{2}{*}{ Size } & & $0.0145^{* * *}$ & & $0.0208^{* * *}$ \\
\hline & & 13.97 & & 15.10 \\
\hline \multirow[t]{2}{*}{ Grow } & & $2.65 \mathrm{e}-06$ & & $-4.40 e-06$ \\
\hline & & 1.39 & & -0.28 \\
\hline \multirow[t]{2}{*}{ ROA } & & $0.245^{* * *}$ & & $0.149^{* * *}$ \\
\hline & & 11.560 & & 8.377 \\
\hline \multirow[t]{2}{*}{ Constant } & $0.095^{* * *}$ & $-0.045^{* *}$ & $0.087^{* * *}$ & $-0.046^{* *}$ \\
\hline & 19.586 & -2.350 & 15.953 & -2.311 \\
\hline Year\&Ind\&Quarter & Control & Control & Control & Control \\
\hline $\mathrm{N}$ & 28497 & 28497 & 20536 & 20536 \\
\hline Adj-R2 & 0.3690 & 0.3826 & 0.8303 & 0.5997 \\
\hline F-Value & $793.77^{* * *}$ & $708.60^{* * *}$ & $4188.08^{* * *}$ & $1078.51^{* * *}$ \\
\hline
\end{tabular}

Note: ${ }^{* * * * *}$, respectively represents the significance levels of $1 \%, 5 \%$ and $10 \%$; under the coefficient is the value $t$, and regulated by White Heteroskedasticity.

From the regression result in Table. 3, the new investment of the company is in negative correlation to the tightness of the current monetary policy. In other words, during the period of tight monetary policy, the corporate investment will significantly decrease, and the correlation coefficient is -0.061; meanwhile, the corporate investment level is in negative correlation to the enterprise level, that is, companies which have more levels in the enterprise level, will invest more, thus proving the first hypothesis in this paper. When considering the influence that both the monetary policy and the enterprise level have on the corporate investment, the regression result indicates that the corporate investment volume is in positive correlation to the interaction term of the tightness of the monetary policy and the enterprise level, the correlative coefficient being 0.017 . Thus it can be seen that the tight monetary policy has an inhibiting effect on the corporate investment, but companies can relieve the financing constraints by building an internal capital market in the enterprise level. The regulating function of the monetary policy has been interfered, so the second hypothesis is verified. 
In order to test the reliability of this paper's conclusion, we have made the following sensitivity analysis: firstly, use the sensitive index of the monetary policy issued by the People's Bank of China to measure the tightness of the monetary policy. Bankers classify the evaluation of the monetary policy into 6 grades: too loose, slightly loose, moderate, slightly tight, too tight and difficult to judge. This paper adopts "slightly tight and too tight", the two grades to measure the tightness of the monetary policy. Bankers think if the monetary policy is slightly tight and its ratio is higher, the tightness degree of the monetary policy is stronger. The advantage of choosing the indicator is that it can more directly measure the tightness of the monetary policy, compared with other indicators such as interest rate, money supply, etc., and moreover, it is not constrained by the macro economic environment; secondly regress after excluding the data of the first and the second quarter in 2007. Since new accounting standards was put into use in 2007, the data of the first and second quarter was in a period when accounting standards are changing, which will probably lead to radical figure regulation, thus affecting test results.

The above regression result of the reliability test is not essentially different from the conclusion of this paper. Due to the length of this paper, the above test results are not reported, but they both have proved the reliability of this paper's conclusion.

\section{Conclusions and Revelations}

Against the background of the transition of the economic system in our country, this paper, from a micro perspective, explores the transmission effect that the macro monetary policy has on the micro corporate capital investment; from the aspect of corporate organizational structure, this paper systematically analyzes the relationship between the enterprise level and the corporate investment, as well as the difference in its influence on the transmission mechanism of the monetary policy; and from a micro perspective, this paper illustrates the reasons why the macro modulation of the monetary policy is weak and twisted in the decision of micro corporate capital investment.

\section{Acknowledgments}

This work is supported by the State Key Program of National Natural Science of China(Grant No.71232004), and Science and technology research project of Chongqing Municipal Education Committee(KJ130658, KJ1400521, KJ1600339).

\section{References}

[1] Guogang Wang; Operating mechanism of Chinese monetary policy tools: 2001-2010. Journal of Economic Research, 12, 4-14 (2012).

[2] Bernanke, B., and Blinder, A.; The Federal Funds Rate and the Channels of Monetary Transmission. American Economic Review, 82(4), 901-921 (1992).

[3] Kashyap, A. K., Stein, J. C., Wilcox,D. W.; Monetary Policy and Credit Conditions: Evidence from the Composition of External Finance. American Economic Review, 83, 78-98 (1993).

[4] Weiwei Ying; Empirical Study of the impact of the economic cycle Investment Firms-Based on the perspective of investment cash flow sensitivity. Journal of Public Finance Research, 5, 30-34 (2008).

[5] Guohua Jiang and Pingui Rao; Monetary policy fluctuation: Bank credit and Accounting Conservatism. Journal of Financial Research, 3, 51-57 (2011). 
[6] La Porta, Rafael, Florencio Lopez-de-Silanes, Andrei Shleifer.; Corporate Ownership around the World. Journal of Finance, 54 (2), 471-517 (1999).

[7] Friedman, Eric, Simon Johnson, Todd Mitton; Propping and tunneling. Journal of Comparative Economics, 31, 732-750 (2003). 